\title{
Evaluation of pure rapeseed oil as a renewable fuel for agricultural machinery based on emission characteristics and long-term operation behaviour of a fleet of 18 tractors
}

\author{
Johannes Ettl ${ }^{1}$ (1) $\cdot$ Heinz Bernhardt ${ }^{2} \cdot$ Georg Huber $^{1} \cdot$ Klaus Thuneke $^{1} \cdot$ Edgar Remmele $^{1} \cdot$ Peter Emberger $^{1}$
}

Received: 8 June 2020 / Accepted: 3 September 2020 / Published online: 19 September 2020

(c) The Author(s) 2020 OPEN

\begin{abstract}
The usage of locally produced pure rapeseed oil fuel (R100) according to fuel standard DIN 51605 in agricultural machinery can contribute to protecting the climate, water, and soil. Besides economic aspects, uncertainties concerning the long-term operation reliability and limited exhaust emissions of R100-operated agricultural machinery are hindering market entry. Thus, the aim of this research is to evaluate field experiences, such as downtimes and repairs, engine oil quality, and cold start behaviour, over a total period of more than 50,000 operation hours with 18 tractors. The tested tractors range from European Union exhaust gas stages I to IV and were configured for the use of R100. Additionally, performance, nitrogen oxides, and particulate matter were measured on a tractor test stand. The tractors demonstrated their full functionality under usual Bavarian farm conditions in daily use. Within the tractor fleet, no serious engine damage was observed, while minor malfunctions and necessary repairs occurred just occasionally. The operational reliability of the tested rapeseed-oil-fuelled tractors seemed to be comparable to that of diesel-fuelled tractors. The results of recurrent power and fuel consumption measurements gave no indication of engine deterioration. Furthermore, measurements proved that differences in exhaust gas emissions between R100 and diesel operation were marginal. Tractor models with exhaust gas after treatment systems were characterized by low emissions of nitrogen oxides and particulate matter in particular. With the 18 tractors running on $\mathrm{R} 100$, about 220 tonnes of $\mathrm{CO}_{2 \text { eq }}$ per year were saved on average from 2015 to 2017 . It can be concluded that the usage of pure rapeseed oil fuel (R100) in compatible agricultural machinery is an implementable alternative to diesel fuel and can make an important contribution to reducing greenhouse gas emissions in agriculture. Nevertheless, there are some challenges to solve, particularly for modern agricultural machines with engines with exhaust gas aftertreatment systems.
\end{abstract}

Keywords Pure plant oil fuel · Biofuel · Agricultural machinery $\cdot$ Operation reliability $\cdot$ Emission

$\begin{array}{ll}\text { Abbreviations } \\ \text { CR } & \text { Common rail } \\ \text { DOC } & \text { Diesel oxidation catalyst } \\ \text { DPF } & \text { Diesel particle filter } \\ \text { EAT } & \text { Exhaust aftertreatment system } \\ \text { ECU } & \text { Engine control unit } \\ \text { FAME } & \text { Fatty acid methyl ester } \\ \text { GHG } & \text { Greenhouse gas } \\ \mathrm{NO}_{X} & \text { Nitrogen oxides }\end{array}$

Johannes Ettl, johannes.ettl@tfz.bayern.de | ${ }^{1}$ Technology and Support Centre in the Centre of Excellence for Renewable Resources, Schulgasse 18, 94315 Straubing, Germany. ${ }^{2}$ School of Life Sciences Weihenstephan, Technical University of Munich (TUM), Dürnast 4, 85354 Freising, Germany.

$\begin{array}{ll}\text { PLN } & \text { Pump line nozzle } \\ \text { PM } & \text { Particulate matter } \\ \text { PTO } & \text { Power take-off } \\ \text { R100 } & \begin{array}{l}\text { 100\% pure, not chemically modified, rapeseed } \\ \text { oil fuel according to fuel standard DIN } 51605\end{array} \\ \text { SCR } & \text { Selective catalytic reduction system } \\ \text { TAN } & \text { Total acid number } \\ \text { TBN } & \text { Total base number }\end{array}$




\section{Introduction}

The reduction of greenhouse gas emissions for climate protection is one of the big challenges of the twenty-first century. Efforts towards the reduction of greenhouse gas (GHG) emissions have to be undertaken by all parts of society. Agriculture is both on the one hand seriously affected by and on the other hand also partly responsible for climate change. According to the German Climate Action Plan 2050, the national agricultural sector must reduce its GHG emissions by 31 to $34 \%$ by 2030 in comparison to its GHG emission level in 1990 [1]. Among other measures like optimised fertiliser management, the reduction of GHGes originating from fossil fuel consumption can play an important role. Pure rapeseed oil fuel (R100) according to fuel standard DIN 51605, which is produced in Bavaria by small-scale oil mills, shows a GHG reduction potential of up to $87.5 \%$ [2]. This considerable share results, among others, from a very low external energy input and the characteristics of most small-scale oil mills obtaining oil seeds and distributing products within a radius usually not larger than $25 \mathrm{~km}[3,4]$. R100 is characterised by fast and complete biodegradability and is non-toxic and therefore especially suitable for agricultural applications, where the machines are mainly operated on non-sealed grounds in ecologically sensitive areas. Hence, the usage of locally produced R100 in agricultural machinery can contribute to climate, water, and soil protection. To ensure sustainability of R100 the EU Renewable Energies Directive II [5] provides the legal framework, which defines sustainability and greenhouse gas emissions saving criteria for all kinds of biofuels. It says for example that biofuels shall not be produced from raw material obtained from land with a high biodiversity value (e.g. primary forest) or a high carbon stock (e.g. peatland). Additionally the origin of biofuels shall be monitored as well as the impact on land use in the EU and the main third countries of supply. Beyond that the production of $\mathrm{R} 100$ comes along with the production of highly valuable protein feed, replacing imported soy and rapeseed is an important crop to diversify agricultural crop rotations.

Many agricultural machines like tractors or combine harvesters have a high energy demand and are in use for a long period daily. Therefore they need a fuel with high energy density to minimise refuelling events. R100 has a similar high net calorific value as diesel fuel (over $34 \mathrm{MJ} \mathrm{dm}^{-3}$ ) and hence fulfils this requirement.

The minimum requirements are determined for pure rapeseed oil as a fuel (R100) in the fuel standard DIN 51605 [6] and generally for pure plant oil as a fuel (also called straight vegetable oil fuel) in DIN 51623 [7]. Besides the high energy density, R100 is characterised by a higher viscosity, higher density, higher surface tension, higher oxygen content and different ignition behaviour compared to diesel fuel, which leads to a different behaviour in the fuel injection system and combustion chamber [8-12]. To take these different properties into account, some modifications of conventional diesel engine systems have to be performed [13-16].

In Europe, fleet tests with tractors showed that reliable operation of modified engines with $\mathrm{R} 100$ is possible [16-20]. Since most of the fleet tests were performed before the year 2011, the engine technology researched is not state of the art today. Furthermore, the documented operation behaviour usually covers only a few operation hours since the research projects have had limited running time.

Besides the steady progress in the development of new tractor components, the fuel quality is of crucial importance for failure-free operation of the tractors. The required fuel quality (DIN 51605) can be supplied by decentralised oil mills by cold pressing with subsequent sorbent treatment and filtration as well as by industrial oil mills [21, 22]. Many of these decentralised oil mills are operated by farmers or farm cooperatives, and the oil seeds typically originate from the local region. The price difference between rapeseed oil and diesel fuel is highly dependent on national tax legislation and the commodity markets. For farmers in Germany, the average price of R100 in comparison to diesel, calculated by the arithmetic mean of monthly recorded values of the last 10 years, differs only slightly. The average price of rapeseed oil fuel is only $0.3 \%$ higher than diesel fuel, but with a relatively high deviation of $\pm 9.2 \%$.

As shown, the use of R100 in tractor engines has already reached a high level of technical development. Nevertheless, there are questions about whether the efficiency, material wear, or exhaust gas emissions change with increasing operation time. Furthermore, the operational reliability of tractors is an important factor for market entry as well as industry and user acceptance.

For many years, test farms of the Bavarian State Ministry of Food, Agriculture and Forestry have used R100 in some of their tractors under scientific monitoring by the Technology and Support Centre.

The aim of this research paper is to evaluate whether R100 can be a promising option to replace fossil diesel fuel in agricultural machinery for GHG emission reduction and protection of finite resources. Therefore, a comprehensive database from the years 2003 to 2017 including operation profiles, engine oil quality, malfunctions, and repairs as well as the power performance of a fleet of 18 tractors comprising different engine technologies and exhaust gas emission stages will be analysed. Furthermore, the emission behaviour of the selected tractors running on R100 
will be investigated and compared to diesel fuel operation. Finally, the challenges that have to be overcome for a broader implementation of R100 in agriculture will be determined.

In the following chapter 'materials and methods', at first tractors and fuels that were used are outlined. After that power and emission measurement, field data acquisition and statistical analysis are described. Chapter 3 shows and discusses the results in terms of operation behaviour, engine oil quality, malfunction and repairs, power performance, emission performance as well as fuel consumption and greenhouse gas emissions. In the final chapter conclusions are drawn and a summary is given.

\section{Materials and methods}

\subsection{Tractors}

Technical data of the 18 monitored tractors are listed in Table 1. The tractors were operated at 10 farms of the Bavarian State Research Centre for Agriculture and at the Technology and Support Centre. Except for tractor 2, which was operated with diesel fuel for the first $250 \mathrm{~h}$, all tractors were operated with R100 from the very beginning after purchase in new condition.

Five of the tractors (nos. 3, 4, 7, 12, and 18) were equipped with a dual fuel management system with R100 and diesel fuel stored in two separate tanks. The engines of these tractors are started and turned off with diesel fuel. The fuel management system is switching automatically to R100 operation when the engine is warmed up and good combustion conditions for $\mathrm{R} 100$ are reached. The exhaust stage IIIA tractors were serial-produced plant-oil tractors of the manufacturers of the brands Fendt and Deutz-Fahr. The fuel system of two further Fendt tractors (nos. 12 and 18) was adapted for diesel and R100 operation by a workshop of BayWa AG, the regional dealer of Fendt tractors in Bavaria. The engine control unit (ECU) settings of tractors $3,4,7,12$, and 18 remained unchanged and hence equal to diesel operation.

All other tractors are optimised for R100 operation. For the two machines with pump line nozzle (PLN) injection systems, this optimisation was conducted by specialised freelance workshops. For the 11 John Deere tractors from exhaust stages IIIA to IV, the optimisation was mainly done by adjusting fuel injection parameters in the engine control unit and by replacing some parts of the low-pressure fuel system (e.g. increased diameter of fuel pipes, more powerful fuel pump). Tractors 5, 6, $11,13,14$, and 17 were prototype tractors that were modified for R100 operation by the European Technology and Innovation Center of John Deere. Tractors 15 and 16 were serial-produced plant-oil tractors of John Deere. For tractors 8, 9 and 10, R100 compatibility was achieved mainly by modifications of the ECU by a specialised freelance workshop. In general, details on ECU parameterisation and modification of hardware are largely confidential information of the manufacturers. Nevertheless, it is typical to compensate the lower energy content of rapeseed oil by increasing the injected fuel quantity. Therefore, the injection period is extended or injection pressure increased. Moreover, for clean and efficient combustion of R100 injection settings, such as timing, pressure and number of partial injections, were adjusted. Finally, the EGR rate was modified to optimise the emission behaviour.

For the conversion from diesel to R100 operation no materials (e.g. filters, seals, rubber components) had to be changed due to material incompatibility. Because of the worldwide fluctuating fuel composition with different shares of biofuel blends in conventional fuels, modern tractors sold in Europe are mostly equipped with biofuel-compatible materials. Materials that have to be avoided are catalytic active metals such as copper in order to resist excessive fuel aging, and elastomers with plant oil solvable plasticisers or a strong shrinkage and swelling behaviour to prevent leakages.

The plant oil compatible tractors, which were supplied by the manufacturers John Deere, Deutz-Fahr and Fendt feature identical warranty conditions and spare parts supply as conventional diesel tractors. If the tractors were customized by independent workshops, latter were either certified by the manufacturer and consequently providing full warranty or they offered extra insurance covering machine breakdown.

Since some of the tractors are equipped with engines of similar base technology, they can be classified into five categories A to $\mathrm{E}$ as follows:

- Category A: Engines with a PLN injection system and without an exhaut aftertreatment system (EAT)

- Category B: Engines with a common rail (CR) injection system and without EAT

- Category C: Engines with a CR injection system and an EAT consisting of a diesel oxidation catalyst (DOC) and selective catalytic reduction (SCR) system for nitrogen oxides reduction

- Category D: Engines with a CR injection system and an EAT consisting of a DOC and a diesel particle filter (DPF)

- Category E: Engines with a CR injection system and an EAT consisting of a DOC, an SCR, and a DPF

Table 1 gives an overview of the researched tractor fleet with technical data and categories. 
Table 1 Technical data of the monitored R100-compatible tractors

\begin{tabular}{|c|c|c|c|c|c|c|c|c|c|}
\hline Category & $\begin{array}{l}\text { Tractor } \\
\text { number }\end{array}$ & Tractor type & $\begin{array}{l}\text { Year of } \\
\text { manufac- } \\
\text { ture }\end{array}$ & $\begin{array}{l}\text { Operation } \\
\text { hours until } \\
\text { end of } 2017\end{array}$ & Exhaust stage & $\begin{array}{l}\text { Number of } \\
\text { cylinders/dis- } \\
\text { placement (-/ } \\
\left.\mathrm{dm}^{3}\right)\end{array}$ & $\begin{array}{l}\text { Rated } \\
\text { power }^{b} \\
(\mathrm{~kW})\end{array}$ & $\begin{array}{l}\text { Fuel } \\
\text { injection } \\
\text { system }\end{array}$ & $\begin{array}{l}\text { Exhaust after- } \\
\text { treatment }\end{array}$ \\
\hline A & 1 & $\begin{array}{l}\text { Fendt Farmer } \\
\text { Vario } 412\end{array}$ & 2003 & 7700 & I & $4 / 3.8$ & 94 & PLN & - \\
\hline A & 2 & $\begin{array}{c}\text { Deutz-Fahr Agro- } \\
\text { tron TTV } 1160\end{array}$ & 2005 & 6100 & II & $6 / 7.1$ & 119 & PLN & - \\
\hline B & 3 & $\begin{array}{l}\text { Fendt } 820 \\
\text { Variogreentec }^{\mathrm{a}}\end{array}$ & 2008 & 5700 & IIIA & $6 / 6.1$ & 152 & CR & - \\
\hline B & 4 & $\begin{array}{l}\text { Fendt } 820 \text { Vario } \\
\text { greentec }{ }^{\mathrm{a}}\end{array}$ & 2009 & 6400 & IIIA & $6 / 6.1$ & 152 & CR & - \\
\hline B & 5 & $\begin{array}{l}\text { John Deere } 6930 \\
\text { (prototype) }\end{array}$ & 2008 & 4900 & IIIA & $6 / 6.8$ & 134 & CR & - \\
\hline B & 6 & $\begin{array}{l}\text { John Deere } 6930 \\
\text { (prototype) }\end{array}$ & 2008 & 4400 & IIIA & $6 / 6.8$ & 134 & CR & - \\
\hline B & 7 & $\begin{array}{l}\text { Deutz-Fahr Agro- } \\
\text { tron } 650 \mathrm{M}^{\mathrm{a}}\end{array}$ & 2010 & 2800 & IIIA & $6 / 6.1$ & 136 & CR & - \\
\hline B & 8 & John Deere 7830 & 2010 & 2650 & IIIA & $6 / 6.8$ & 173 & CR & - \\
\hline B & 9 & John Deere 6630 & 2010 & 2900 & IIIA & $6 / 6.8$ & 96 & $\mathrm{CR}$ & - \\
\hline B & 10 & John Deere 6630 & 2012 & 1900 & IIIA & $6 / 6.8$ & 96 & $\mathrm{CR}$ & - \\
\hline B & 11 & $\begin{array}{l}\text { John Deere } \\
\text { 5080R (proto- } \\
\text { type) }\end{array}$ & 2013 & 950 & IIIA & $4 / 4.5$ & 59 & $C R$ & - \\
\hline C & 12 & $\begin{array}{l}\text { Fendt Vario } 718 \\
\mathrm{SCR}^{\mathrm{a}}\end{array}$ & 2012 & 1300 & IIIB & $6 / 6.1$ & 92 & CR & DOC, SCR \\
\hline D & 13 & $\begin{array}{l}\text { John Deere } \\
6210 R \text { (proto- } \\
\text { type) }\end{array}$ & 2012 & 3000 & IIIB & $6 / 6.8$ & 154 & CR & DOC, DPF \\
\hline D & 14 & $\begin{array}{l}\text { John Deere } \\
6125 R \text { (proto- } \\
\text { type) }\end{array}$ & 2013 & 2450 & IIIB & $4 / 4.5$ & 92 & CR & DOC, DPF \\
\hline D & 15 & $\begin{array}{l}\text { John Deere } \\
\text { 6115R }\end{array}$ & 2014 & 550 & IIIB & $4 / 4.5$ & 85 & CR & DOC, DPF \\
\hline D & 16 & $\begin{array}{l}\text { John Deere } \\
\text { 6100RC }\end{array}$ & 2014 & 1300 & IIIB & $4 / 4.5$ & 74 & CR & DOC, DPF \\
\hline E & 17 & $\begin{array}{l}\text { John Deere } \\
6210 \mathrm{R} \text { (proto- } \\
\text { type) }\end{array}$ & 2012 & 2400 & IV & $6 / 6.8$ & 154 & CR & DOC, DPF, SCR \\
\hline$E$ & 18 & $\begin{array}{l}\text { Fendt } 724 \text { Vario } \\
\text { S4 }{ }^{\mathrm{a}} \text { (prototype) }\end{array}$ & 2014 & 1450 & IV & $6 / 6.1$ & 174 & CR & DOC, DPF, SCR \\
\hline
\end{tabular}

PLN pump line nozzle, $C R$ common rail, DOC diesel oxidation catalyst, DPF diesel particle filter, SCR selective catalytic reduction ${ }^{a}$ The tractor is equipped with a fuel management system and a second fuel tank with diesel fuel for engine start and turn off ${ }^{\mathrm{b}}$ Rated power in diesel fuel operation

The John Deere tractors of categories D and $E$ in serial diesel application are equipped with an active particle filter regeneration system. This automatic diesel injection in the particle filter for the regeneration event was switched off because investigations by Düsseldorf [23] showed that passive regeneration is sufficient for the DPF system of these engines when operated with R100. The interventions in the exhaust aftertreatment were carried out and approved by the manufacturer.

The regeneration of the EAT of tractor 18 is started manually by the machine operator after receiving a regeneration request from the tractor control system. The machine operator switches the fuel management system to diesel fuel operation and starts the automated serial 
regeneration process. Thereby, the temperature increase is caused by post-injection of diesel fuel into the combustion chamber. Regeneration with R100 is not possible since the post-injection parameters are not optimised for R100 operation.

\subsection{Fuels}

The R100 for the tractors during field demonstration was produced exclusively by decentralised oil mills in Bavaria. Hereby, the rapeseed is cold-pressed in a screw press. Additionally, an adsorbent is added to the oil to separate $\mathrm{P}, \mathrm{Ca}$, and $\mathrm{Mg}$ compounds. The oil is purified by two-stage filtration. The fuel quality of every batch delivered to the farms was analysed according to the quality-related parameters of DIN 51605 as listed in Table 2.

Besides R100, some of the tractors used a limited quantity of conventional diesel fuel according to DIN EN 590 (e.g. tractors with a fuel management system). Some important properties of R100 and diesel fuel are shown in Table 3. The kinematic viscosity of rapeseed oil at $40^{\circ} \mathrm{C}$ is about 15 times higher than the kinematic viscosity of diesel fuel. Additionally the viscosity of rapeseed oil is increasing exponentially with decreasing temperature. In a temperature range of -5 to $+5^{\circ} \mathrm{C}$ R100 is crystallizing, but this process is completely reversible. As a consequence in DIN 51605 it is stated that: "With respect to the winter capability of a vegetable oil-compatible combustion engine operated with rapeseed oil fuel, an unproblematic cold start shall be ensured. As a rule, this is to be achieved by means of suitable technical measures applied to the vegetable oil-compatible combustion engine, since fuel producers only have a limited influence on winter capability. Since accepted test methods such as the Cold Filter Plugging Point (CFPP) cannot be used for rapeseed oil fuel, this standard does not contain any requirements which could be covered by measuring and limit value."The lower net calorific value of rapeseed oil fuel in comparison to diesel fuel is an effect of the presence of oxygen in the molecule leading to less combustion air required.

For the power and emission measurements, the same R100 according to DIN 51605 was used as in field operations. The diesel fuel at the tractor test stand complied with CEC legislative fuel RF 06-03 based on test procedure ISO 8178-1 [18, 24-27].

\subsection{Power and emission measurement}

For power and emission measurements, tractors were used which are representative for the fleet in terms of engine technology, exhaust gas aftertreatment and fuel system. The power and emission behaviour of the tractors
Table 2 Monitored quality parameters, limit values, and used test methods for pure rapeseed oil fuel (R100) according to DIN 51605 [6]

\begin{tabular}{|c|c|c|c|}
\hline Parameter & Unit & Limit & Method \\
\hline $\begin{array}{l}\text { Oxidation stability at } \\
110^{\circ} \mathrm{C}\end{array}$ & $\mathrm{h}$ & $\min .6 .0$ & DIN EN 14112 \\
\hline Contamination & $\mathrm{mg} \mathrm{kg}^{-1}$ & $\max .24$ & DIN EN 12662 \\
\hline Acid value & $\mathrm{mg} \mathrm{KOH} \mathrm{g}^{-1}$ & $\max .2 .00$ & DIN EN ISO 660 \\
\hline Water content & $\mathrm{mg} \mathrm{kg}^{-1}$ & $\max .750$ & DIN EN ISO 12937 \\
\hline Sulfur content & $\mathrm{mg} \mathrm{kg}^{-1}$ & $\max .10 .0$ & DIN EN ISO 20884 \\
\hline Phosphorous content & $\mathrm{mg} \mathrm{kg}^{-1}$ & $\max .3 .0$ & DIN 516276 \\
\hline Calcium content & $\mathrm{mg} \mathrm{kg}^{-1}$ & $\max .1 .0$ & DIN 516276 \\
\hline Magnesium content & $\mathrm{mg} \mathrm{kg}^{-1}$ & $\max .1 .0$ & DIN 516276 \\
\hline
\end{tabular}

Table 3 Typical properties of pure rapeseed oil fuel (R100) and diesel fuel [24]

\begin{tabular}{llll}
\hline Property & Unit & $\begin{array}{l}\text { R100 } \\
\text { DIN 51605 }\end{array}$ & $\begin{array}{l}\text { Diesel } \\
\text { fuel } \\
\text { EN 590 }\end{array}$ \\
\hline Density at $15^{\circ} \mathrm{C}$ & $\mathrm{kg} \mathrm{m}^{-3}$ & 920 & 835 \\
Kinematic viscosity at $40^{\circ} \mathrm{C}$ & $\mathrm{mm}^{2} \mathrm{~s}^{-1}$ & 35.5 & 2.31 \\
Net calorific value & $\mathrm{MJ} \mathrm{kg}^{-1}$ & 37.1 & 42.6 \\
Carbon & $\mathrm{kg} \mathrm{kg}^{-1}$ & 0.774 & 0.865 \\
Hydrogen & $\mathrm{kg} \mathrm{kg}^{-1}$ & 0.117 & 0.136 \\
Oxygen & $\mathrm{kg} \mathrm{kg}^{-1}$ & 0.109 & - \\
\hline
\end{tabular}

was measured at a tractor test stand. The main parts of the test stand are the eddy-current brake, gas analysers, a partial-flow-dilution system for particulate matter (PM), a fuel balance, and an electronic data acquisition system based on LabView ${ }^{\mathrm{TM}}$ from National Instruments Corp. (Austin, United States). Detailed descriptions of the test stand can be found in Emberger et al. [24] and Ettl et al. [28].

The power, torque, and speed at the tractor power take-off (PTO) were measured by an Eggers PT 301 MES dynamometer from KL Maschinenbau GmbH \& Co. KG (Rendsburg, Germany) according to OECD Code 2 [29].

The engine speed was calculated using the transmission ratio. The fuel consumption of the tractor was measured by continuous weighing of an external fuel tank using a platform scale KB60.2 from Mettler-Toledo $\mathrm{GmbH}$ (Gießen, Germany). Therefore, the low-pressure fuel lines of the tractor were connected to the external tank. The injected fuel mass per stroke was calculated from the fuel consumption and the engine speed. During the measurements, the ambient air temperature and the combustion air inlet temperature of the tractors were controlled at $25^{\circ} \mathrm{C} \pm 3 \mathrm{~K}$. 
The carbon monoxide $(\mathrm{CO})$, carbon dioxide $\left(\mathrm{CO}_{2}\right)$, nitrogen monoxide (NO), and nitrogen dioxide $\left(\mathrm{NO}_{2}\right)$ concentrations in the exhaust gas were measured using a Sesam 4 Fourier-transformation-infrared spectroscope from AVL Emission Test Systems (Graz, Austria). The nitrogen oxides $\left(\mathrm{NO}_{X}\right)$ emissions are stated as the sum of $\mathrm{NO}$ and $\mathrm{NO}_{2}$. The hydrocarbon emissions were detected using an FID4000hh flame ionisation detector from AVL Emission Test Systems (Graz, Austria).

The concentration of particulate matter in the exhaust gas was determined using a partial-flow dilution tunnel according to ISO 8178-1. The particles were collected on polytetrafluoroethylene-coated glass-fibre filters [Emfab ${ }^{\mathrm{TM}}$ from Pall (Port Washington, New York, USA)]. The filters were conditioned and weighed in a climatic chamber according to ISO 8178-1 using a XP56 micro-balance from Mettler-Toledo GmbH (Gießen, Germany).

For the emission measurements of tractors on a test bench, no standard is available. In several research projects, a procedure based on ISO 8178-1 was used [18, 24-27] and showed good reproducibility in a small-scaled round robin test [26]. Here, the tractors were operated using the $\mathrm{C} 1$ test cycle according to ISO 8178-4. This test cycle is equivalent to the NRSC (non-road stationary cycle). The emission results presented were measured using the same procedure.

\subsection{Acquisition of field test data}

All tractors were equipped with a logbook. The drivers had to record the following parameters for every day of operation:

- operation hours

- fill level of engine oil

- classification of the cold start behaviour in four categories:"no start", "poor", "medium", or "good"

- type of work

- quantity of pure rapeseed oil fuel used for fuelling

- quantity of diesel used for fuelling

- quantity of urea solution used for refilling

- quantity of engine oil used for refilling

- malfunctions and failures

Furthermore, some of the tractors were equipped with a data-logging system that recorded the selected parameters of the Controller Area Network (CAN) bus and of a differential pressure sensor of the particulate filter of tractor 13.

For tractors $1,2,3,5,6,12,13,17$, and 18, engine oil samples were taken and analysed at intervals of $50 \mathrm{~h}$. The tractors were selected to cover the relevant engine categories ranging from 56 to $175 \mathrm{~kW}$. For the analysis, about
$100 \mathrm{ml}$ of engine oil was taken. The amount of extracted engine oil was so low that no refilling with fresh engine oil was required. The analysis was done by Oelcheck $\mathrm{GmbH}$, Germany. The following parameters were analysed:

- Plant oil fuel content according to DIN 51639-4

- Total acid number (TAN) according to ASTM D 664

- Total base number (TBN) according to DIN ISO 3771

- Kinematic viscosity at 40 and $100^{\circ} \mathrm{C}$ according to ASTM 7279

- Wear metal content according to DIN 51363-1

- Additive content according to DIN 51363-1

\subsection{Statistical analysis}

A linear regression analysis was undertaken to find the relations between the parameters of engine oil quality, power performance, and the pressure difference between the inlet and outlet of the DPF and the operation time. Therefore, the software package Origin Pro 9.1 (OriginLab Corporation, Northampton, USA) was used.

\section{Results and discussion}

\subsection{Operation behaviour}

Figure 1 shows the share of work the tractors had to perform in the time period from 2015 to 2017. Depending on the structure of the farm (i.e. size, livestock, share of grassland and arable land), the tractors were used for a wide range of different types of work. However, the test tractors carried out work types (e.g. transporting, ploughing, cultivating, harrowing or mowing) that are comparable to the working profiles of conventional diesel fuelled tractors under Bavarian farming conditions.

Because of the different physical properties of R100 compared to diesel fuel (e.g. higher viscosity), cold start and idling are challenging operation points. Figure 2 shows the evaluation of the engine cold start by the tractor operators. The cold start behaviour of the tractors is predominantly rated as good or medium. Tractors $3,4,7$, and 12 , which feature a dual fuel management system, where the cold start is done with diesel fuel, usually performed a good engine start. Also, tractor 18 is equipped with a dual fuel management system, but because of irregular malfunction of the switchover valve in the low-pressure fuel system, no start was possible on four days during the three years of operation. The cold start behaviour of the tractors which operate solely with R100 is judged to be slightly less positive but still good or medium for more than $75 \%$ of the cold starts. For four of these tractors, only on one day during the 
three years a start was not possible. For tractor 5 , this was caused by damage to the starter motor after $3500 \mathrm{~h}$ of operation. For the other tractors, exchanging the fuel filter solved the problem. The cold start behaviour is not directly related to the ambient temperature. This is because for plant oil compatible combustion engines suitable technical measures, such as heating devices, are applied to ensure good cold start behaviour. However, at low temperatures, technical deficiencies in the fuel system (such as weak aged fuel pumps, air in the pipes) or in the preheating systems (such as defective fuses) become more obvious.

In summary, the technical reliability of the tractors running on R100 seems to be more or less the same as that of diesel-fuelled tractors. However, manufacturers should pay special attention to optimising the cold start behaviour and fuel system.

\subsection{Engine oil quality}

The $\mathrm{R} 100$ content in the engine oil of the tractors is shown in Fig. 3. The tractors in engine category $A$ show a much higher plant oil intake into the engine oil than the tractors in the other engine categories. After an operation time of $200 \mathrm{~h}$, the engine oil was diluted, reaching an R100 content of more than $0.1 \mathrm{~g} \mathrm{~g}^{-1}$. The origins of the fuel intake can be leakages in the engine-oil-lubricated high-pressure unit pumps and injected fuel that was sprayed on the cylinder liner and washed into the engine oil. In contrast to diesel fuel and similarly to fatty acid methyl esters (FAME), R100 does not evaporate out of the engine oil under usual conditions because of its higher distillation curve but accumulates during the engine oil operation time [30,

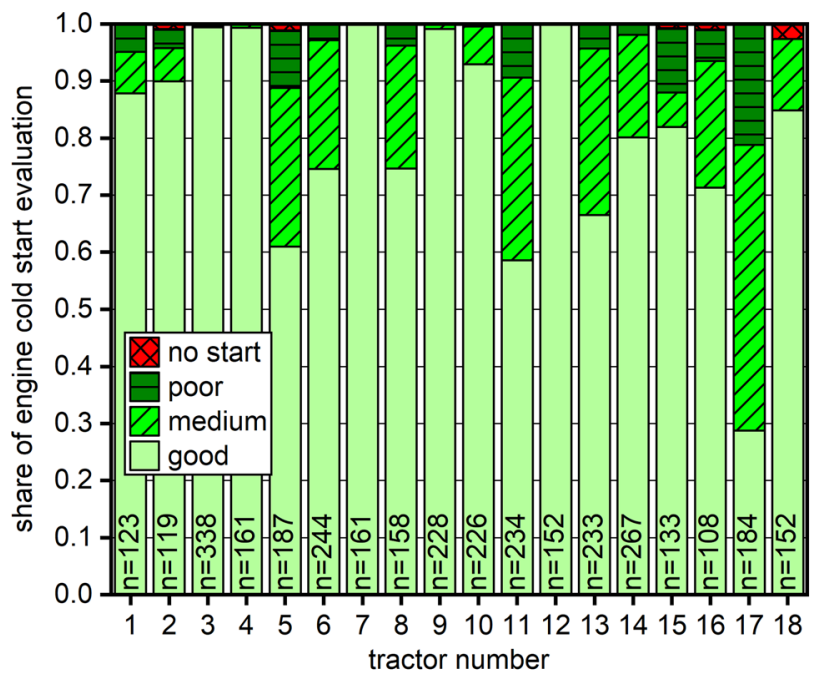

Fig. 2 Evaluation of engine cold start in the years 2015 to 2017 for the 18 tractors ( $n$ : number of documented cold starts)

31]. A high content of $R 100$ in the engine oil increases the risk of oil polymerisation and subsequent engine damage [31]. Limit values for acceptable R100 content are not well defined and vary between 0.06 and $0.25 \mathrm{~g} \mathrm{~g}^{-1}$ [32]. Hence, the engine oil drain interval was reduced from 500 to $250 \mathrm{~h}$ for these tractors.

In contrast, with fuel content values under $0.05 \mathrm{~g} \mathrm{~g}^{-1}$, after $500 \mathrm{~h}$ of operation time, the tractors of engine category $B$ are characterised by a low intake of R100. The tractors are equipped with $C R$ injection systems, where the high pressure is generated by a fuel-lubricated high-pressure pump (tractors 5 and 6 ) or two engine-oil-lubricated high-pressure unit pumps (tractor 3 ). In comparison to the

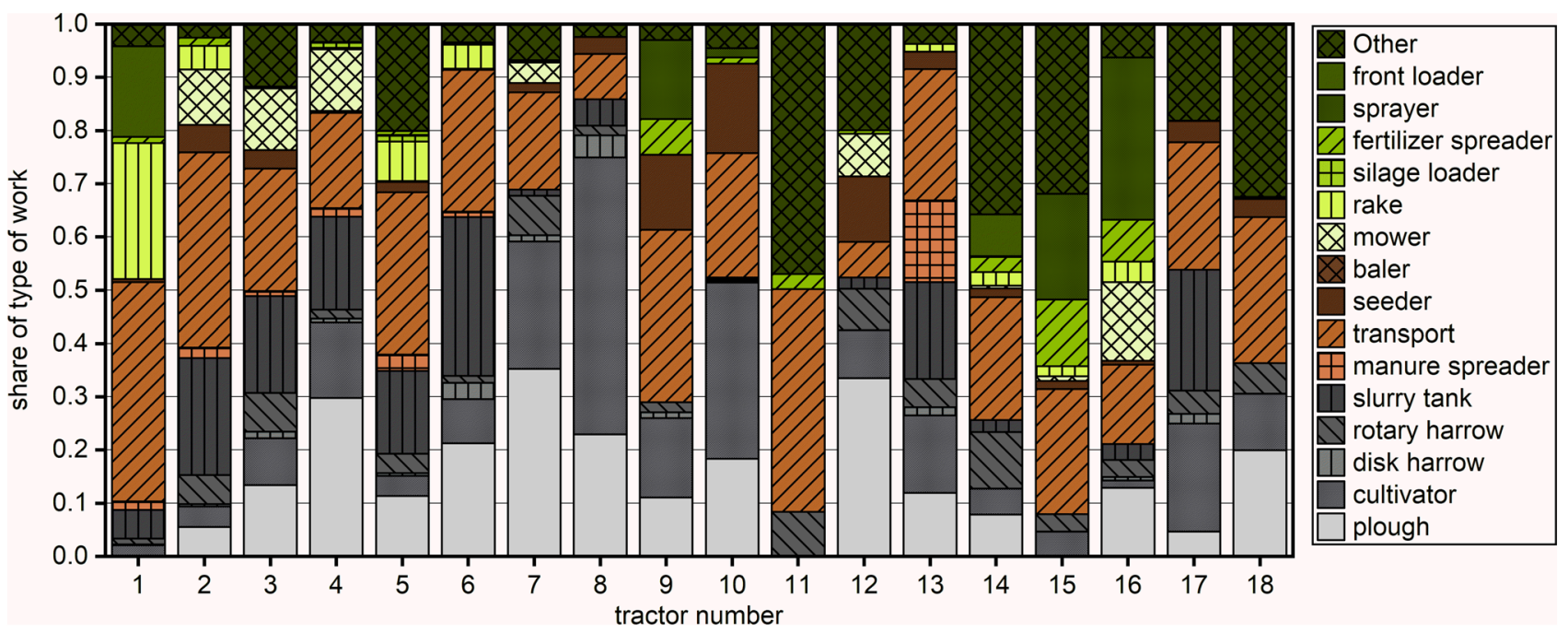

Fig. 1 Share of types of works of the tractors for the years 2015 to 2017 
tractors of engine category $A$, which were equipped with four (tractor 1) and six (tractor 2) engine-oil-lubricated unit pumps, the number of possible leakages in the fuel system for the tractors of engine category $B$ is less. Furthermore, tractor 3 is equipped with a dual fuel management system, where the cold start of the engine is performed with diesel fuel. Especially at cold start and during engine warm up, unfavourable conditions for mixture preparation in the combustion cylinder prevail and the risk of wetting the cylinder wall with fuel is higher, especially for plant oils that are characterised by high viscosity. For tractors 5 and 6 , the cold start behaviour with R100 was optimised by adaptation of the injection timing and pressure within the engine control unit. The low fuel intake rates of these tractors, which are at the same level as for tractor 3 with the fuel management system, indicate high-quality optimisation for R100 operation.

For the tractors of engine categories $C$ to $E$, low fuel intake into the engine oil far below $0.10 \mathrm{~g} \mathrm{~g}^{-1}$ of fuel after $500 \mathrm{~h}$ of operation time can be observed as well, except for tractor 18. Overall, the data basis for the tractor 18 is still too small to indicate a clear reason for the increasing R100 content in the engine oil (e.g. postinjections of fuel, incorrect operation during cold starts carried out with R100).

Further results of engine oil analysis focus on engines of the categories $B$ to $E$ with $C R$ injection systems.

The results of total acid number (TAN) and total base number (TBN) of the engine oils are shown in Fig. 4. For the tractors of engine category $B$, the TAN of the engine oils increased by $0.3 \mathrm{mg} \mathrm{KOH} \mathrm{g}^{-1}$ per $100 \mathrm{~h}$ of operation on average. About the same was observed for the tractors of engine categories $C, D$, and $E$, with an average increase of TAN between 0.2 and $0.4 \mathrm{mg} \mathrm{KOH} \mathrm{g}^{-1}$ per $100 \mathrm{~h}$. The TBN decreases with increasing operation time of the engine oil between 0.2 and $0.5 \mathrm{mg} \mathrm{KOH} \mathrm{g}^{-1}$ per $100 \mathrm{~h}$ on average for the tractor engine oils. After $500 \mathrm{~h}$ of operation, which is the regular draining interval, the relative decrease did not exceed a level of $50 \%$. An engine oil drain is recommended when the TBN is reduced by $50 \%$ from the initial value [33]. The decrease in TBN is at about the same level as the increase in TAN. After $500 \mathrm{~h}$ of operation time of the engine oil, the TBN is still higher than the TAN. Furthermore, the TAN does not show an accelerated increase. These factors indicate a sufficient alkaline reserve of the engine oil.

The resulting alkaline reserve of the engine oil after $500 \mathrm{~h}$ of operation time is dependent on the starting level of TBN. The ash-reduced engine oils of the John Deere tractors and tractor 18 are characterised by a lower starting TBN. The reason for the lower TBN might be that the additives for controlling the TBN often contain ash-forming elements and are therefore reduced.
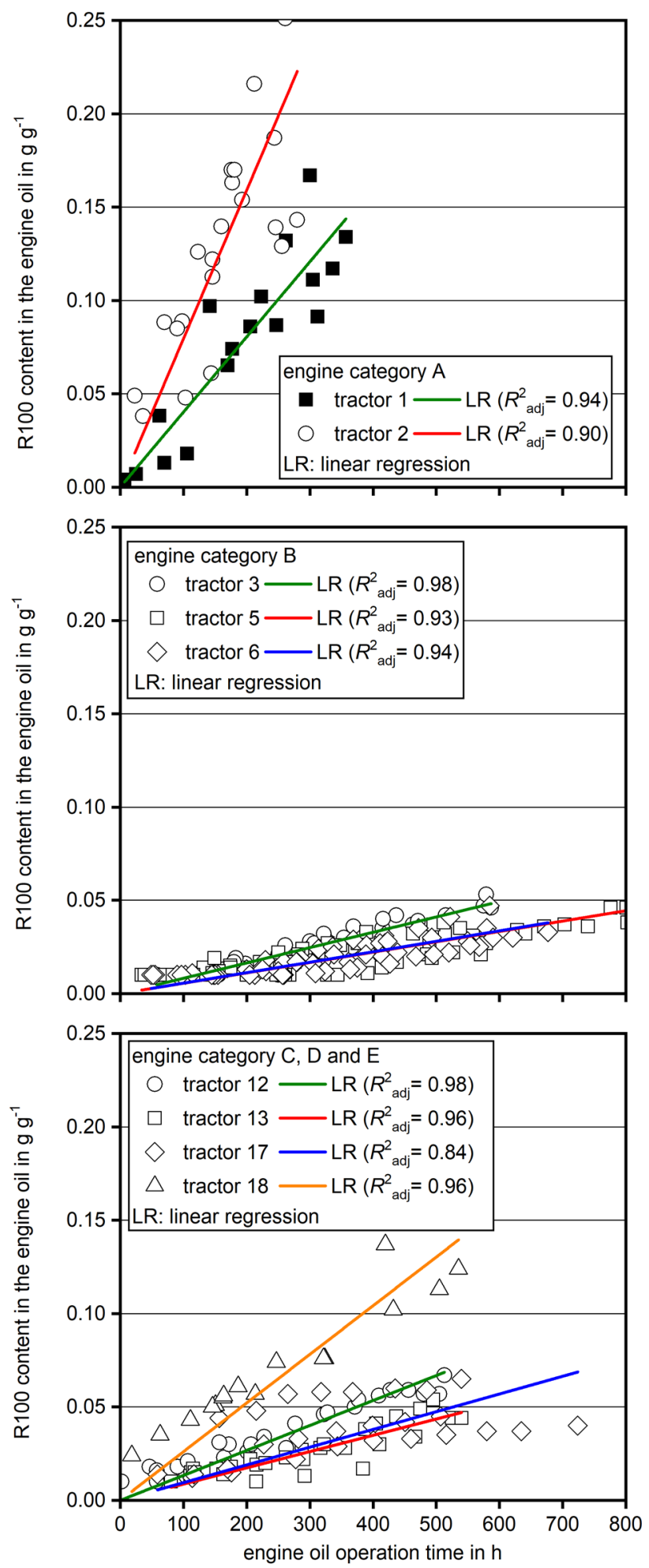

Fig. 3 Pure rapeseed oil fuel (R100) content in engine oil in relation to the engine oil operation time for different tractors in the defined tractor categories 
Figure 5 shows the development of the iron content in the engine oil of the different tractors. Iron in the engine oil is a result of wear of different engine parts. The average increase of iron content varies between 4 and $8 \mathrm{mg} \mathrm{kg}^{-1}$ after $100 \mathrm{~h}$ of operation for the different tractors and can be assessed as uncritical. For example, the warning limit for iron defined by John Deere is $50 \mathrm{mg} \mathrm{kg}^{-1}$ per $100 \mathrm{~h}$ of operation time of the engine oil [20].

Also, for the other wear metals, no problematic concentrations in the engine oils were observed. The additive content and the analysed kinematic viscosity of the engine oils were also inconspicuous. The results of engine oil analysis do not indicate excessive wear or malfunction of engine parts.

\subsection{Malfunction and repairs}

No serious engine damage was observed for any tractor. The most cost-intensive repair concerning the engine was incurred for tractor 1 after $7000 \mathrm{~h}$, to replace a broken control rack for the unit fuel pumps. This damage was not caused by R 100 operation.

For tractors 1, 2, 5, and 6, after around 3000 to $4000 \mathrm{~h}$, the low-pressure fuel pump had to be replaced. The cost of the pumps was below $500 €$ each. Since pure rapeseed oil is characterised by a higher viscosity compared to diesel fuel, it can be expected that the pumps are working at higher load, which may cause a shortening of the lifetime. Tractors 5, 6, 8, 9, and 10 are equipped with similar engines, and for this engine a malfunction of a relief valve at the CR was observed after around 1000 to $2000 \mathrm{~h}$ of operating time with R100. For two tractors, cleaning the valve was sufficient to solve the problem, and for the other tractors, this valve was replaced as it is not cost intensive. This malfunction was recognised once for each of these tractors but not again during ongoing operation time.

Tractors 3 and 4 had problems with air in the low-pressure rapeseed oil fuel system within the first year of operation. As a consequence, the fuel management system only allowed diesel fuel operation during most of the time. The reason was a tiny crack in an inspection glass on the fuel filter. Furthermore, the fuel switchover valve of tractor $3 \mathrm{had}$ to be replaced twice. Additionally, a damaged switchover valve was also replaced on tractor 18 .

Beside this, some other repairs that were not linked to R100 operation were necessary, such as damage to electronic or transmission parts. Small repairs, such as on the electronic or on screw connections were comparable to conventional diesel according to the information from the service workshops.

Considering that the usage of R100 in tractors is not common practice, the number and expenditure of
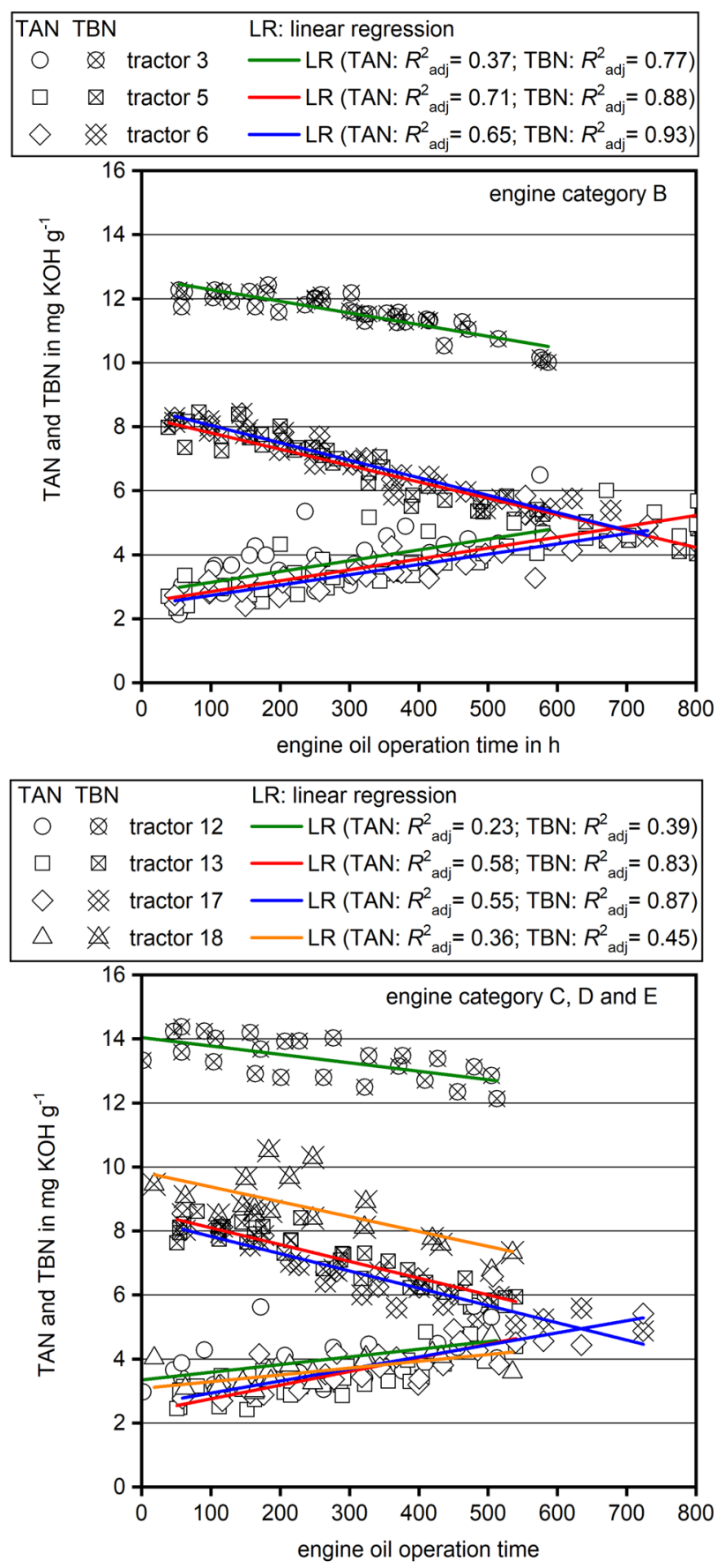

Fig. 4 Total acid number (TAN) and total base number (TBN) of the engine oil in relation to the engine oil operation time for different tractors in the defined tractor categories

necessary repairs of the 18 plant oil tractors were rather low. This shows that reliable long-term operation of plantoil-fuelled tractors is possible. 

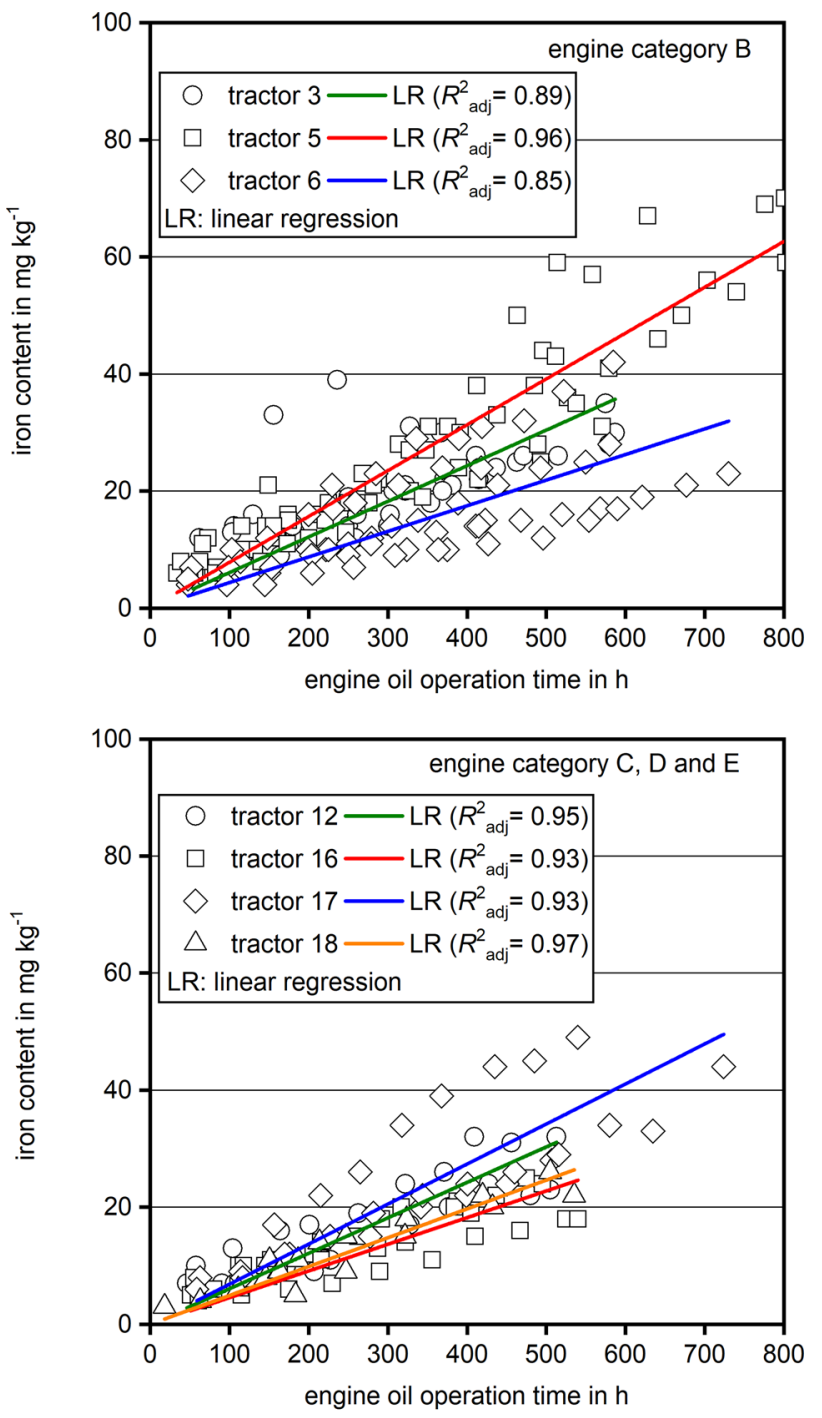

Fig. 5 Iron content of the engine oil in relation to the engine oil operation time for different tractors

\subsection{Power performance}

The power performance.of seven tractors was measured according to OECD Code 2 [29] several times at different tractor ages. It has to be considered that the maintenance of the tractors was carried out according to the manufacturer's recommendations. Figure 6 shows the power at the power take-off (PTO power) at rated speed and full load. For all tractors, the variation of PTO power over operating time is within $\pm 5 \%$. Simple linear regression analysis shows no significant influence of the operating time on the PTO power except for tractors 5 and 18. A significant increase of PTO power over operation time is calculated for tractor 5, while a decrease is calculated for tractor 18 . Except for tractor 18, no trend of a significant power loss that might indicate engine malfunction is observable.

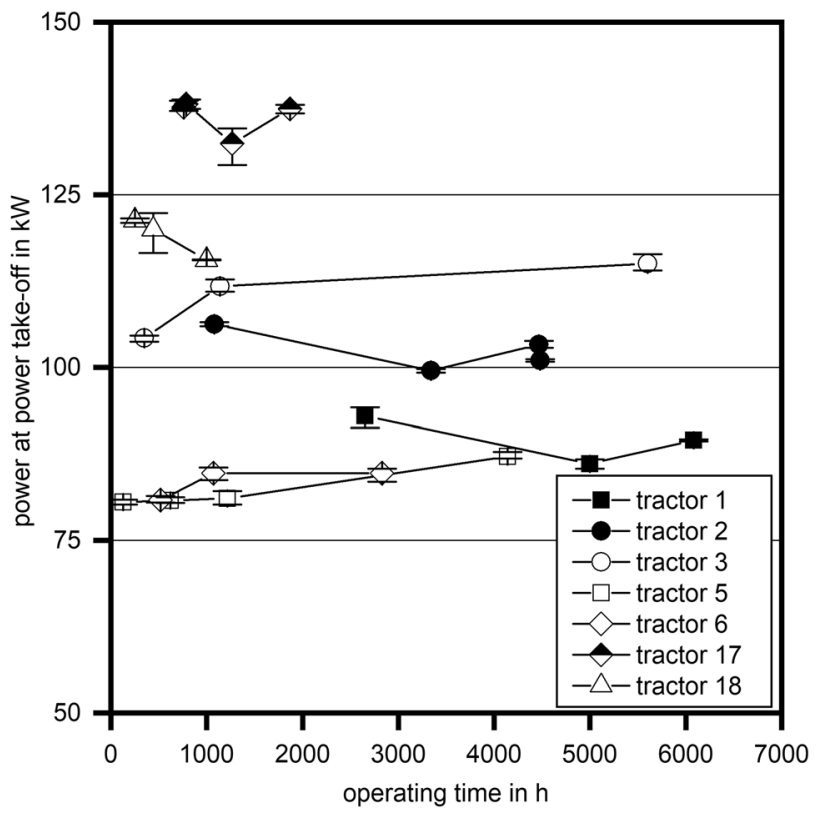

Fig. 6 Power at the power take-off (arithmetic mean and maximum deviation, $n=3$ ) of the tractors at rated speed and full load at different operating times with pure rapeseed oil fuel operation (R100)

Since there are some 100 operation hours in practice and some years between the PTO power measurements of the tractors, the range of variation is assessed as non-critical. The variations might result from different conditions of the engine, transmission, and auxiliary equipment but also minor differences in framework conditions during the measurements. For tractor 18 , the detected power loss was $5 \mathrm{~kW}$ within $750 \mathrm{~h}$ of operation.

The injected mass of rapeseed oil per stroke at rated speed and full load is shown in Fig. 7. The injected mass of rapeseed oil varies by $\pm 4 \%$ during the operation time of the tractors and partially explains the differences in PTO power. Except for tractor 18, no trend of a significant decrease of the injected mass R100 per stroke that might indicate unusual deterioration of the fuel injection system is detectable.

For the most modern tractor, no. 18, the injection mass of R100 decreases significantly over time, which explains the power loss. One reason for the reduced injection mass may be the formation of injector deposits. Injector deposits can affect the hydraulic flow in the injector nozzle holes, resulting in a reduced fuel flow rate and injection quantity [34-36]. Especially modern engines with more sophisticated fuel injection equipment are more prone to form different types of deposits in connection with the fuel type and quality [37]. This trend can also be seen for the most modern tractor, no. 18, within the R100 tractor fleet using the PTO power and injection quantity as indicators, but further results are needed. 


\subsection{Emission performance}

The emission performance of the tractors is evaluated on the basis of nitrogen oxides $\left(\mathrm{NO}_{\chi}\right)$ and particulate matter (PM) emissions, since these are the most relevant exhaust components for diesel engines. Figure 8 shows the results of the emission measurements of the tractors fuelled with R100 and diesel fuel, except for tractor 17, where only measurements with R100 were performed. With increasing exhaust gas stage of the tractors, which in a way represent the technical evolution, the emissions of $\mathrm{NO}_{x}$ and PM decrease for both fuels. For the tractors of engine categories $A$ and $B$ (tractors 1, 2, 4, 5, and 6), which were not equipped with exhaust gas aftertreatment systems, up to $25 \%$ higher $\mathrm{NO}_{X}$ and up to $60 \%$ lower PM emissions were observed with R100 than with diesel fuel. Tractor 12 shows about the same $\mathrm{NO}_{X}$ emissions with both fuels but higher $P M$ with R100. This tractor features a DOC and SCR system for reduction of $\mathrm{NO}_{X}$ but no DPF. In contrast, tractor 13 is equipped with a DPF, which explains the low but similar PM concentrations for both fuels. The same applies to the $\mathrm{NO}_{x}$ emissions of tractor 13 . Tractors 17 and 18, which comply with exhaust stage IV, are equipped with DOC, DPF, and SCR systems. While the $\mathrm{NO}_{X}$ emissions of tractor 18 are equal for both fuels, PM emissions are lower during R100 operation than with diesel fuel. Although diesel fuel was not investigated for tractor 17 , the results with R100 of both exhaust stage IV tractors correspond well with each other. The low levels of $\mathrm{NO}_{x}$ and $\mathrm{PM}$ emissions

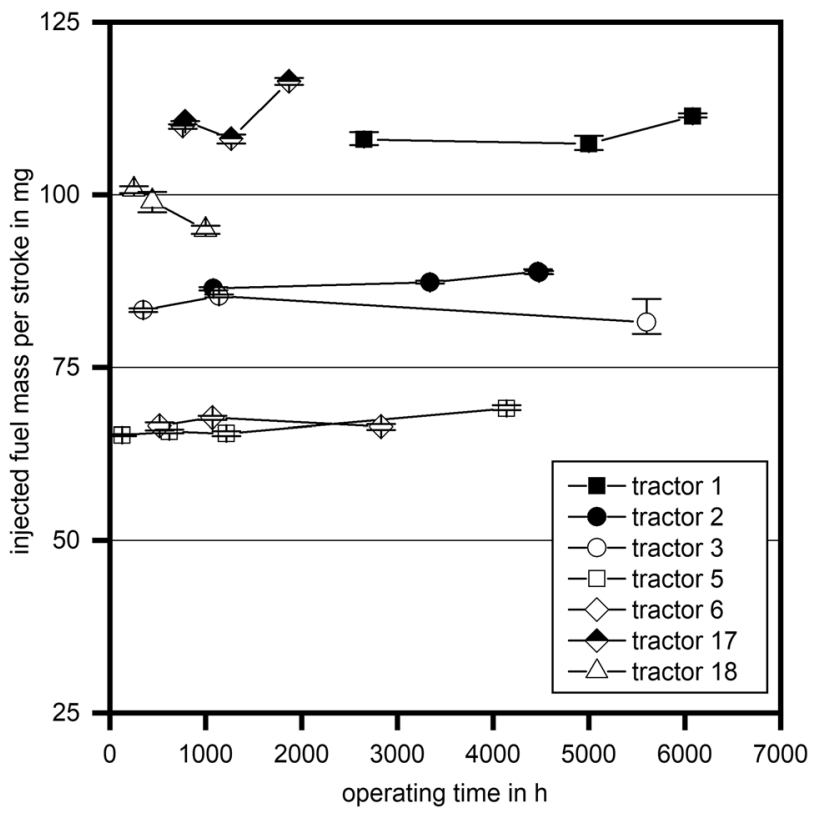

Fig. 7 Injected fuel mass per stroke (arithmetic mean and maximum deviation, $n=3$ ) of the tractors at rated speed and full load at different operating times demonstrate the high effectiveness of exhaust gas aftertreatment systems during R100 operation.

Higher $\mathrm{NO}_{x}$ emissions of diesel engines without the SCR system fuelled with R100 compared to diesel fuel were also observed in previous research, especially at higher engine load $[8,17,18,38,39]$. This is probably a result of several overlaid effects, as discussed in detail in Emberger et al. [8], and is also proposed to explain the higher $\mathrm{NO}_{X}$ emissions of FAME compared to diesel [40-44].

Summarising, it can be stated that the emission behaviour of the investigated tractors does not show any extensive deviation between R100 and diesel fuel operation. Furthermore, new tractor models with exhaust gas aftertreatment systems including SCR and DPF are characterised by low $\mathrm{NO}_{X}$ and $\mathrm{PM}$ emissions in particular.

Six John Deere tractors (13-17) of exhaust stages IIIB and IV are equipped with a DPF and an upstream DOC, enabling continuous DPF regeneration (continuously regenerating trap). In diesel serial application, the DPF regeneration is usually done by actively dosing an additional amount of diesel fuel either in the cylinder at the end of combustion or in the exhaust stream before the oxidation catalyst. The resulting temperature increase of the exhaust gas through fuel oxidation in the catalyst leads to oxidation of the soot in the DPF. Because of the high viscosity and evaporation temperature of rapeseed oil, the dosing system does not work with R100. Thus, it had to be deactivated and the tractors were operated with passive regeneration instead. By solely passive regeneration it is intended to achieve a balance of the separated and oxidised plant oil soot quantity in the DPF, as shown by Düsseldorf [23]. To prove this theory, tractor 13 was equipped with a data-logging system to evaluate the pressure difference over the DPF during operation (logging frequency of $1 \mathrm{~Hz}$ ). The resulting pressure difference of the DPF is an effect of not only the amount of soot and ash but also the mass flow of exhaust gas, which depends on the speed and load of the engine. For analysis of the pressure difference, only values where the engine speed was within the range of 1700 to $2100 \mathrm{rpm}$ and the engine load was between 70 and $100 \%$ were considered. The measured pressure difference over a period of $2000 \mathrm{~h}$ is shown in Fig. 9. Although data were only used from a certain range of engine speeds and loads, a high variation of the pressure difference can still be noticed. Nevertheless, no excessive increase in differential pressure over a period of $2000 \mathrm{~h}$ was observed, and hence the passive regeneration of the DPF during R100 operation is suitable for long-term operation. There are multiple reasons for this. The oxidation reactivity of soot from vegetable oil combustion is higher than that of diesel [45], which leads to lower soot oxidation temperatures. Furthermore, the exhaust gas temperature in 

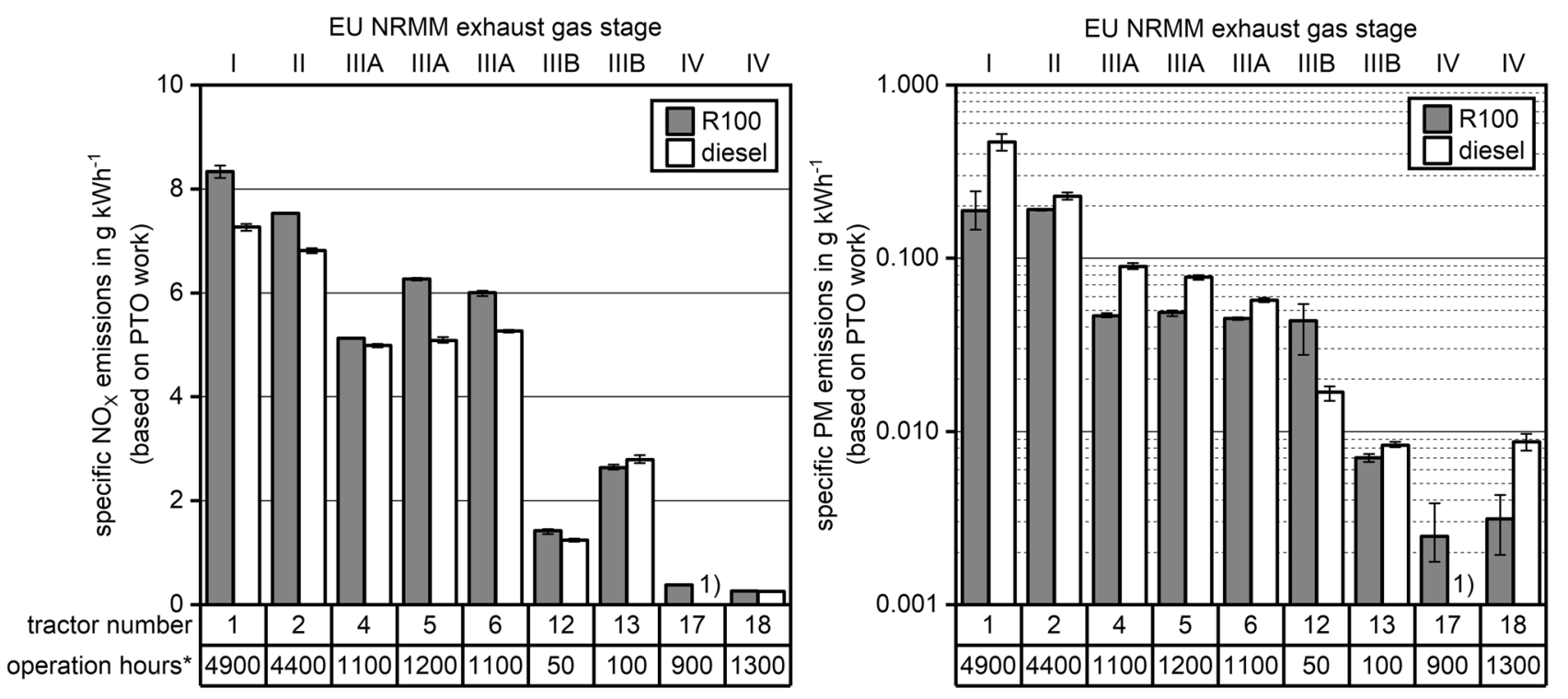

*at the time of measurement; 1) not measured

Fig. 8 Specific $\mathrm{NO}_{X}$ and PM emissions (arithmetic mean and maximum deviation, $n=3$ ) of the tractors applying the non-road-stationarycycle

the DPF during many standard farm operations exceeds $300^{\circ} \mathrm{C}$ for longer time periods, which allows long-term reliable and efficient passive DPF regeneration [46].

A linear regression analysis of the pressure data shows that the differential pressure increases by around $0.7 \mathrm{kPa}$ in $1000 \mathrm{~h}$. This increase can be explained by the continuous deposition of ashes in the DPF that originate mainly from additives in the engine lubricant $[46,47]$.

Besides tractor 13, the other five tractors with deactivated active regeneration systems were also operated without failures related to the DPF. This was favoured by tractor working profiles with recurrent high load operation. However, the possibility that passive regeneration will be insufficient for other DPF types and for tractors performing mainly low load operation cannot be excluded. Under these circumstances, active DPF regeneration with R100 will probably become necessary.

\subsection{Fuel consumption and greenhouse gas emissions}

In the years 2015 to 2017 , the tractors consumed $233.777 \mathrm{~m}^{3}$ of R100 and $38.765 \mathrm{~m}^{3}$ of diesel fuel (Table 4). For 10 tractors, the share of R100 in the total fuel consumption was $0.95 \mathrm{~m}^{3} \mathrm{~m}^{-3}$ or higher. All these tractors were John Deere tractors that were optimised for R100 combustion, even at cold start. Tractors 1, 2, and 5 were also optimised for R100 combustion during cold start but show a lower share of R 100 consumption of 0.69 to $0.76 \mathrm{~m}^{3} \mathrm{~m}^{-3}$. For these tractors, a higher share would have

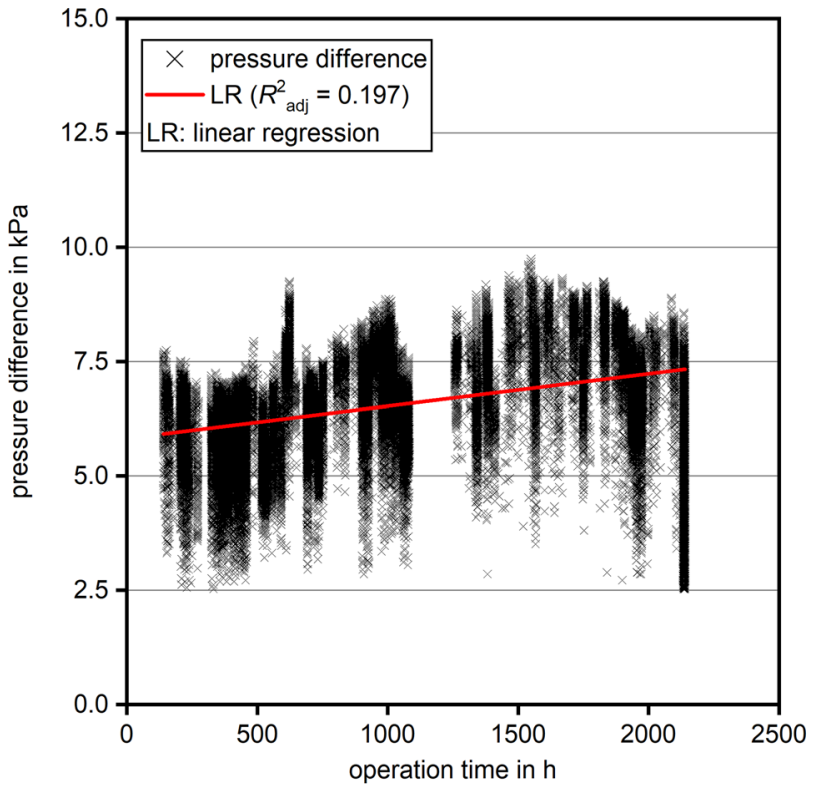

Fig. 9 Differential pressure of the diesel particulate filter of tractor 13 at 70 to $100 \%$ load and a speed range of 1700 to 2100 rpm over $2000 \mathrm{~h}$ without active regeneration

been possible. These tractors were all located at the same farm and because of difficulties in the supply of R 100 the tractors were temporarily operated with diesel fuel.

Tractors 3, 4, 7, 12, and 18 were equipped with a dual fuel management system, where some diesel fuel is always needed for cold starts. Four of the tractors also showed a 
rather high R100 share of 0.74 to $0.82 \mathrm{~m}^{3} \mathrm{~m}^{-3}$; tractor 3 , however, showed a lower share of $0.57 \mathrm{~m}^{3} \mathrm{~m}^{-3}$. The reason for this is that the operator drove the machine for about five months with only diesel fuel for organisational reasons on the farm.

Analysis of the R100 quality showed that the requirements of DIN 51605 are met for most of the delivered fuel batches. In the years 2015 to 2017 , only one clear violation was recognised for one batch, where the content of calcium was $1.7 \mathrm{mg} \mathrm{kg}^{-1}$ instead of the maximum limit of $1.0 \mathrm{mg} \mathrm{kg}^{-1}$. The high fuel quality is the basis for reliable operation of the plant-oil-fuelled tractors.

The co-product from rapeseed oil is press cake, which is used as animal feed. For the calculation of GHG emissions, the life cycle analysis data of Dressler et al. [2] was used, since they assessed region-specific data. They reported specific GHG emissions of $11.9 \mathrm{~g} \mathrm{CO}_{2 \mathrm{eq}} \mathrm{MJ}^{-1}$ from pure rapeseed oil from decentralised oil production in Bavaria, considering the substitution of soy meal by rapeseed cake and the land use change by soy cultivation in South America [2]. Taking into account the lower calorific value of R100 (34.5 MJ dm$\left.{ }^{-3}\right)$, the GHG emissions of the tractors amount to a total of $95.98 \mathrm{t} \mathrm{CO}_{2 \text { eq }}$ for the three years 2015 to 2017. Supplying the same energy content by diesel fuel would have resulted in $758.14 \mathrm{tCO}_{2 \text { eq }}$ assuming specific GHG emissions of $94 \mathrm{~g} \mathrm{CO}_{2 \text { eq }} \mathrm{MJ}^{-1}$ as suggested by the European Council [5]. In total, $662.16 \mathrm{tCO}_{2 \text { eq }}$ or $30.3 \mathrm{tCO}_{2 \text { eq }}$ per 1000 operating hours were saved with all 18 tractors in the years 2015 to 2017.

\section{Summary and conclusions}

Eighteen plant-oil-compatible tractors were investigated in terms of operation and emission behaviour over a period of more than 50,000 working hours in sum. The eldest tractor was operated for 14 years with R100. The tractors within the monitored fleet covered a wide range of engine systems from EU exhaust stages I to IV.

Full functionality of the tractors was proved during daily use under usual Bavarian farm conditions. The cold start behaviour was predominantly rated as good or medium. Engine oil quality shows differences over the operation time regarding grade of dilution, resulting in specific draining intervals. For the tractors with pump-line-nozzle injection systems, a shortening of the standard drain interval is advisable, whereas for the tractors with common rail engines it is not necessary. No serious engine damage was observed within the tractor fleet. The number of and expenditure on malfunctions and repairs of the tractors were low considering that the usage of R100 in tractors is not yet common practice. The technical reliability of the pure plant oil fuelled tractors is comparable to that of diesel fuelled tractors.
Table 4 Fuel consumption of the monitored tractors in the years 2015 to 2017

\begin{tabular}{llrrrl}
\hline $\begin{array}{l}\text { Tractor } \\
\text { number }\end{array}$ & Tractor type & $\begin{array}{l}\text { Operation } \\
\text { time }(\mathrm{h})\end{array}$ & $\begin{array}{l}\text { R100 DIN } \\
51605\left(\mathrm{~m}^{3}\right)\end{array}$ & $\begin{array}{l}\text { Diesel fuel DIN } \\
\text { EN 590 }\left(\mathrm{m}^{3}\right)\end{array}$ & $\begin{array}{l}\text { Share of } \\
\mathrm{R} 100\left(\mathrm{~m}^{3}\right. \\
\left.\mathrm{m}^{-3}\right)\end{array}$ \\
\hline 1 & & 1100 & 5.374 & 1.685 & 0.76 \\
2 & Fendt Farmer Vario 412 & 967 & 9.469 & 2.979 & 0.76 \\
3 & Deutz-Fahr Agrotron TTV 1160 & 2234 & 15.303 & 11.448 & 0.57 \\
4 & Fendt 820 Variogreentec & 2345 & 24.478 & 8.399 & 0.74 \\
5 & Fendt 820 Vario greentec & 1389 & 10.125 & 4.647 & 0.69 \\
6 & John Deere 6930 & 1551 & 16.781 & 0.459 & 0.97 \\
7 & John Deere 6930 & 976 & 13.927 & 3.227 & 0.81 \\
8 & Deutz-Fahr Agrotron 650 M & 1065 & 23.111 & 0.405 & 0.98 \\
9 & John Deere 7830 & 1103 & 12.224 & 0.519 & 0.96 \\
10 & John Deere 6630 & 1129 & 13.185 & 0 & 1.00 \\
11 & John Deere 6630 & 649 & 4.318 & 0.244 & 0.95 \\
12 & John Deere 5080R & 798 & 10.516 & 2.235 & 0.82 \\
13 & Fendt Vario 718 SCR & 1680 & 24.036 & 0 & 1.00 \\
14 & John Deere 6210R (prototype) & 1316 & 12.625 & 0 & 1.00 \\
15 & John Deere 6125R & 567 & 4.164 & 0.075 & 0.98 \\
16 & John Deere 6115R & 653 & 3.758 & 0.010 & 1.00 \\
17 & John Deere 6100RC & 1139 & 17.337 & 0 & 1.00 \\
18 & John Deere 6210R (prototype) & 1222 & 13.046 & 2.433 & 0.84 \\
& Fendt 724 Vario S4 (prototype) & 21883 & 233.777 & 38.765 & \\
\hline & SUM & & & & \\
\hline
\end{tabular}


The results of recurrent power and fuel consumption measurements gave no indication of a change in engine performance, except for the most modern tractor. For this tractor, deposit formation in the fuel injection system is assumed but could not be clarified in this study. Furthermore, the measurements prove that the emission behaviour of the researched tractors does not show extensive deviation compared to diesel fuel operation and new tractor models with exhaust gas aftertreatment systems are characterised by low $\mathrm{NO}_{X}$ and PM emissions in particular.

The monitored R100 quality was predominantly very good and within the specifications of DIN 51605, which is the basis for reliable engine operation. In the last three years of operation, the monitored fleet consumed around $234 \mathrm{~m}^{3}$ of rapeseed oil fuel and saved GHG emissions of around $662.16 \mathrm{t} \mathrm{CO}_{2 \text { eq }}$ compared to diesel fuel operation.

Summarising, it can be concluded that in principle the usage of R100 in plant-oil-fuel-compatible agricultural machines seems to be possible and can make an important contribution to reducing GHG emissions in agriculture.

Nevertheless there are some challenges to overcome, particularly for modern agricultural machines featuring engines with exhaust gas aftertreatment systems. It is unclear to what extent deposits in the fuel injection system of pure-plant-oil-compatible machines are built up and how they can be controlled to avoid power loss or engine malfunction, if necessary.

Furthermore, less information is available about the long-term behaviour of modern engines and exhaust gas aftertreatment systems, especially for machinery fulfilling the EU non-road emission stage V. Technical solutions for the active regeneration of the exhaust gas aftertreatment system as well as the cold start behaviour with R100 must be researched to get comfortable solutions for marketable products.

Acknowledgements The authors would like to thank the Bavarian State Ministry of Food, Agriculture and Forestry, the Bavarian State Ministry of Economic Affairs, Regional Development and Energy, and the German Federal Ministry of Food and Agriculture (BMEL) through the Agency for Renewable Resources (FNR) for the financial support within several different projects. We would also like to thank AGCO Fendt GmbH, BayWa AG, the John Deere European Technology and Innovation Center, and John Deere Werke Mannheim for cooperation and for supporting the research work with prototype tractors. Furthermore, the authors would like to thank the Bavarian State Research Center for Agriculture (LfL) for the excellent collaboration.

Funding Open Access funding enabled and organized by Projekt DEAL.

\section{Compliance with ethical standards}

Conflict of interest On behalf of all authors, the corresponding author states that there is no conflict of interest.

Open Access This article is licensed under a Creative Commons Attribution 4.0 International License, which permits use, sharing, adaptation, distribution and reproduction in any medium or format, as long as you give appropriate credit to the original author(s) and the source, provide a link to the Creative Commons licence, and indicate if changes were made. The images or other third party material in this article are included in the article's Creative Commons licence, unless indicated otherwise in a credit line to the material. If material is not included in the article's Creative Commons licence and your intended use is not permitted by statutory regulation or exceeds the permitted use, you will need to obtain permission directly from the copyright holder. To view a copy of this licence, visit http://creativecommons .org/licenses/by/4.0\%.

\section{References}

1. Bundesministerium für Umwelt, Naturschutz, Bau und Reaktorsicherheit (2016) Klimaschutzplan 2050: Klimaschutzpolitische Grundsätze und Ziele der Bundesregierung. Bundesministerium für Umwelt, Naturschutz, Bau und Reaktorsicherheit (BMUB), Berlin

2. Dressler D, Thuneke K, Remmele E (2018) GHG emissions of rapeseed oil fuel-impact of specific data and balance methods. In: Persson M, Scarlat N, Grassi A et al (eds) Papers of the 26th European biomass conference. ETA-florence renewable energies; WIP_renewable energies, Florence, Munich, pp 1639-1643

3. Haas R, Remmele E (2013) Dezentrale Ölsaatenverarbeitung 2012/2013-eine bundesweite Befragung. Berichte aus dem TFZ, Straubing

4. Engelmann K, Strimitzer L, Remmele E (2014) Environmental effects of decentralized rapeseed oil production in Bavaria-a life cycle assessment (LCA) case study. In: Agroscope, Eidgenössische Technische Hochschule Zürich, European Society of Agricultural Engineers (eds) Engineering for improving resource efficiency: proceedings. Agroscope; Eidgenössische Technische Hochschule Zürich (ETH), Zurich, pp 1-8

5. European Parliament, European Council (2018) Directive (EU) $2018 / 2001$ of the European parliament and of the council of 11 December 2018 on the promotion of the use of energy from renewable sources. Off J Eur Union 5(328):82-209

6. German Institute for Standardization (2016) DIN 51605:2016. Fuels for vegetable oil compatible combustion engines-fuel from rapeseed oil-requirements and test methods

7. German Institute for Standardization (2015) DIN 51623:2015. Fuels for vegetable oil compatible combustion engines-fuel from vegetable oil-requirements and test methods

8. Emberger P, Hebecker D, Pickel P et al (2015) Ignition and combustion behaviour of vegetable oils after injection in a constant volume combustion chamber. Biomass Bioenergy 78:48-61. https://doi.org/10.1016/j.biombioe.2015.04.009

9. Li Q, Backes F, Wachtmeister G (2015) Application of canola oil operation in a diesel engine with common rail system. Fuel 159(1):141-149. https://doi.org/10.1016/j.fuel.2015.06.060

10. Lüft M, Bernhardt S, Velji A et al. (2007) Optimization of injection of pure rape seed oil in modern diesel engines with directinjection. SAE technical paper 2007-01-2031. https://doi. org/10.4271/2007-01-2031 
11. Koder A, Altmann R, Rabl H-P et al (2014) Injection rate analysis of a modern diesel injection system using straight vegetable oils as fuel. In: Agroscope, Eidgenössische Technische Hochschule Zürich, European Society of Agricultural Engineers (eds) Engineering for improving resource efficiency: proceedings. Agroscope; Eidgenössische Technische Hochschule Zürich (ETH), Zurich, pp 1-8

12. Vojtíšek-Lom M, Pechout M, Barbolla A (2012) Experimental investigation of the behavior of non-esterified rapeseed oil in a diesel engine mechanical fuel injection system. Fuel 97:157165. https://doi.org/10.1016/j.fuel.2012.02.055

13. Lawlor V, Olabi A (2015) Review of scientific research regarding PPO, tallow and RVO as diesel engine fuel. Fuel 145:25-38. https ://doi.org/10.1016/j.fuel.2014.12.034

14. Basinger $M$, Reding T, Williams $C$ et al (2010) Compression ignition engine modifications for straight plant oil fueling in remote contexts: modification design and short-run testing. Fuel 89(10):2925-2938. https://doi.org/10.1016/j.fuel.2010.04.028

15. Kohler M, Eckel H (eds) (2009) Pflanzenöl als Kraftstoff in landwirtschaftlichen Maschinen. KTBL-Schrift, vol 478. Kuratorium für Technik und Bauwesen in der Landwirtschaft e.V. (KTBL), Darmstadt

16. Thuneke K, Emberger $P$ (2013) New plant oil compatible tractors-experiences and development in Germany. In: Eldrup A, Baxter D, Grassi A et al (eds) Setting the course for a biobased economy: 21 st European biomass conference and exhibition. Proceedings. ETA-Florence Renewable Energies, Florence, Italy, pp 1666-1669

17. Hassel E, Wichmann V, Schümann U et al (2006) Practice operation of serial rape seed oil suitable engines-results of the demonstration project. Landtechnik 61(1):14-15. https://doi. org/10.15150/lt.2006.1037

18. Rathbauer J, Krammer K, Zeller R et al (2009) Pure plant oil as alternative fuel for agriculture? In: Verein Deutscher Ingenieure e. V. (VDI), Max-Eyth-Gesellschaft Agrartechnik (MEG) (eds) Innovations to meet future challenges: conference: agriculture engineering. VDI-Verlag, Düsseldorf, pp 211-216

19. Emberger $P$, Thuneke $K$, Gassner T et al (2010) Emission characteristics of new vegetable oil compatible exhaust gas stage IIIA tractors. In: Spitzer J, Dallemand JF, Baxter D et al (eds) From research to industry and markets: proceedings of the european conference. ETA-Florence Renewable Energies, WIP-Renewable Energies, Florence, Italy, pp 1775-1778

20. The 2ndVegOil Consortium (2012) 2nd generation pure plant oil: [publishable final project report]. Agrartechnische Berichte aus Sachsen-Anhalt, vol 6. Martin-Luther-Universität Halle-Wittenberg Institutsbereich Agrartechnik, Halle

21. Remmele E, Stotz K (2004) Quality of rapeseed oil as a fuel for adapted diesel engines: field survey. In: Swaaij WPM, Fjällström T, Helm P et al (eds) Second world biomass conference-biomass for energy, industry and climate protection: proceedings of the world conference. ETA-Florence Renewable Energies, Florence, $\mathrm{pp}$ 1526-1528

22. Thuneke K, Remmele E (2007) Production and utilisation of rapeseed oil fuel in Germany. In: Bartz WJ (ed) Fuels 2007. Technische Akademie Esslingen (TAE), Ostfildern, pp 383-388

23. Düsseldorf C (2015) Experimentelle Untersuchungen zur inner- und außermotorischen Partikelreduktion an einen Nutzfahrzeugdieselmotor zur Erfüllung der Abgasstufe IV im Betrieb mit biogenen Kraftstoffen, Als Ms. gedr. VKM-Schriftenreihe, vol 15. Techn. Univ, Kaiserslautern

24. Emberger P, Hebecker D, Pickel P et al (2016) Emission behaviour of vegetable oil fuel compatible tractors fuelled with different pure vegetable oils. Fuel 167:257-270. https://doi.org/10.1016/j. fuel.2015.11.071
25. Müllerová D, Landis M, Schiess I et al (2011) Operating parameters and emission evaluation of tractors running on diesel oil and biofuel. Res Agric Eng 57:35-42

26. Emberger $P$, Landis $M$, Krammer $K$ et al (2011) Measurement of emissions of a tractor-round robin test of ART, FJ-BLT and TFZ. Landtechnik 66(1):56-59. https://doi.org/10.15150/lt.2011.353

27. Siedlecki M, Lijewski P, Weymann S (2017) Analysis of tractor particulate emissions in a modified NRSC test after implementing a particulate filter in the exhaust system: MATEC web of conferences 118, 0028. In: Polish Scientific Society of Combustion Engines (ed) VII international congress on combustion engines. Board of polish scientific society of combustion engines, Poznan, Poland, pp 1-7

28. Ettl J, Bernhardt H, Pickel P et al (2018) Transfer of agricultural work operation profiles to a tractor test stand for exhaust emission evaluation. Biosyst Eng 176:185-197. https://doi. org/10.1016/j.biosystemseng.2018.10.016

29. Organisation for Economic Co-operation and Development (OECD) (2010) OECD standard codes-general texts, code 2-for the official testing of agricultural and forestry tractors: February 2010. Organisation for Economic Co-operation and Development (OECD), Paris

30. Gili F, Igartua $A$, Luther $R$ et al (2011) The impact of biofuels on engine oil performance. Lubr Sci 23(7):313-330. https://doi. org/10.1002/ls.158

31. Thuneke K, Rocktäschel A, Remmele E (2003) Interaction between rapeseed oil fuel and motor oil. Landtechnik 58(5):310 311. https://doi.org/10.15150/lt.2003.1517

32. Hassel E, Prescher K, Berndt S et al (2005) Praxiseinsatz von serienmäßigen neuen rapsöltauglichen Traktoren. Lehrstuhl für Kolbenmaschinen und Verbrennungsmotoren der Universität Rostock, Rostock

33. Bartz WJ (2010) Einführung in die Tribologie und Schmierungstechnik: Tribologie-Schmierstoffe-Anwendungen. expertVerl., Renningen

34. Birgel A, Richards $P$, Ladommatos $N$ et al (2012) Investigations on deposit formation in the holes of diesel injector nozzles. SAE Int J Fuels Lubr 5(1):123-131. https://doi.org/10.4271/2011-01-1924

35. Ullmann J, Geduldig M, Stutzenberger H et al (2008) Investigation into the formation and prevention of internal diesel injector deposits. SAE technical paper 2008-01-0926. https://doi. org/10.4271/2008-01-0926

36. Hoffmann $\mathrm{H}$ (2018) A contribution to the investigation of internal diesel injector deposits. Dissertation, RWTH Aachen; Shaker Verlag $\mathrm{GmbH}$

37. Stepien Z, Mazanek A, Suchecki A (2017) Impact of fuel on real diesel injector performance in field test. Proc Inst Mech Eng Part D J Auto Eng 232(8):1047-1059. https://doi.org/10.1177/09544 07017725671

38. Czerwinski J, Zimmerli Y, Mayer A et al (2009) Alternative diesel fuels (GTL, RME, ROR) and (nano) particle emissions. In: Bartz WJ (ed) Fuels 2009: mineral oil based and alternative fuels. Technische Akademie Esslingen (TAE), Ostfildern, pp 115-127

39. Paulsen HM, Wichmann V, Schuemann U et al (2011) Use of straight vegetable oil mixtures of rape and camelina as on farm fuels in agriculture. Biomass Bioenergy 35(9):4015-4024. https ://doi.org/10.1016/j.biombioe.2011.06.031

40. Lapuerta M, Armas O, Rodríguez-Fernández J (2008) Effect of biodiesel fuels on diesel engine emissions. Prog Energy Combust Sci 34(2):198-223. https://doi.org/10.1016/j. pecs.2007.07.001

41. Mueller CJ, Boehman AL, Martin GC (2009) An experimental investigation of the origin of increased NOx emissions when fueling a heavy-duty compression-ignition engine with soy biodiesel. SAE technical paper 2009-01-1792. https://doi. org/10.4271/2009-01-1792 
42. Ye P, Boehman AL (2012) An investigation of the impact of injection strategy and biodiesel on engine NOx and particulate matter emissions with a common-rail turbocharged DI diesel engine. Fuel 97(7):476-488. https://doi.org/10.1016/j. fuel.2012.02.021

43. Sun J, Caton JA, Jacobs TJ (2010) Oxides of nitrogen emissions from biodiesel-fuelled diesel engines. Prog Energy Combust Sci 36(6):677-695. https://doi.org/10.1016/j.pecs.2010.02.004

44. Hoekman SK, Robbins C (2012) Review of the effects of biodiesel on NOx emissions. Fuel Process Technol 96(4):237-249. https:// doi.org/10.1016/j.fuproc.2011.12.036

45. Agudelo JR, Álvarez A, Armas O (2014) Impact of crude vegetable oils on the oxidation reactivity and nanostructure of diesel particulate matter. Combust Flame 161(11):2904-2915. https:// doi.org/10.1016/j.combustflame.2014.05.013
46. Guan B, Zhan R, Lin H et al (2015) Review of the state-of-theart of exhaust particulate filter technology in internal combustion engines. J Environ Manage 154:225-258. https://doi. org/10.1016/j.jenvman.2015.02.027

47. Sappok A, Wong VW (2011) Lubricant-derived ash properties and their effects on diesel particulate filter pressure-drop performance. J Eng Gas Turbines Power 133(3):32805. https://doi. org/10.1115/1.4001944

Publisher's Note Springer Nature remains neutral with regard to jurisdictional claims in published maps and institutional affiliations. 